\title{
The Evolution of Taste and Perinatal Programming of Taste Preferences
}

\author{
Š. PODZIMEK ${ }^{1}$, M. DUŠKOVÁ ${ }^{2,3}$, Z. BROUKAL ${ }^{1}$, B. RÁCZ ${ }^{2}$, L. STÁRKA ${ }^{2}, J_{\text {. DUŠKOVÁ }}{ }^{1}$ \\ ${ }^{1}$ Institute of Dental Medicine, First Faculty of Medicine, Charles University, Prague, Czech \\ Republic, ${ }^{2}$ Institute of Endocrinology, Prague, Czech Republic, ${ }^{3}$ Department of Medicine Strahov, \\ General University Hospital, Prague, Czech Republic
}

Received August 18, 2018

Accepted September 13, 2018

\begin{abstract}
Summary
Taste is important for food intake. The fetus first experiences taste through amniotic fluid, and later via mother's milk. Early human experience with taste has a key importance for later acceptance of food. Dietary behavior is determined by the interaction of many different factors. The development of the olfactory and taste receptors begins at 7-8 weeks of gestation. An early sensitive period probably exists when flavor preference is established. Sweet taste is preferred in early childhood; this is the reason why children are at increased risk of over-consuming saccharides. Gustatory sensitivity declines with age. The threshold for the perception of each basic taste differs, and is established genetically. In this review, we summarize published data on taste preferences and its development and changes during life.
\end{abstract}

\section{Key words}

Taste perception • Flavor preference • Sweet • Salty • Sour • Umami • Bitter

\section{Corresponding author}

M. Dušková, Institute of Endocrinology, Národní 8, 11694 Prague 1, Czech Republic. E-mail: mduskova@endo.cz

\section{Introduction}

Taste is an important protective sense, evolved to drive food intake and aid in the avoidance of poisons. Flavor is a product of several sensory systems, mostly of the chemical senses, taste and smell. The first experience with flavors occurs prior to birth when the flavor of amniotic fluid changes according to the mother's diet
(Mennella et al. 1995). Some of these flavors continue to be experienced in mother's milk. Flavor components, ingested or inhaled, as for example tobacco, are transmitted to the amniotic fluid and to the maternal milk (Mennella and Beauchamp 1991). This means that the mother's diet has key importance to the later acceptance of foods, preferably of palatable and in taste richer foods. Some vegetables that contain anticarcinogenic compounds have a bitter taste (for example cauliflower, broccoli). Fruits rich in vitamins and antioxidants are sour (Liu 2013). Dietary behavior is determined by interaction of many different factors, such as social, community, family and individual factors including availability and costs of different foods and sociocultural eating habits (Raine 2005). The acceptance of healthy foods has a significant impact connected to many chronic, called as noncommunicable, diseases (diabetes mellitus, metabolic syndrome, cardiovascular diseases, childhood obesity and dental caries), which are associated with poor food choice.

\section{Taste versus flavor and sensation}

Taste can be determined as a sensation caused by the chemical reaction of a substance with the receptors of taste cells, which are located in the oral cavity, mostly on the taste buds of the tongue. Each taste bud contains 50-100 cells, which are localized on the palate, throat, epiglottis, or esophagus (Breslin and Spector 2008). The cells are connected to a sensory neuron, and one neuron can serve more cells simultaneously, so it can transmit different tastes accordingly. We cannot taste with our 
lips, the underside of our tongue, our hard palate, or the inside of our cheeks. Young children may have taste buds in more areas of the oral cavity than adults. Five basic tastes exist: sweet, salty, bitter, sour, umami (savory). Each taste cell has multiple receptors for all the basic tastes, but usually only one or two taste receptors are active in one cell. The flavor is the result of the simultaneous effect of the taste, smell (n. olfactorius) and stimulation of the trigeminal nerve, the so-called chemesthetic sensation, which is able to register the texture, temperature, carbonation, or tear induction (e.g. by onions) (Lawless and Heyman 1999). Odors are recognized by olfactory receptors, which are located on a small patch of tissue in the nasal cavity. The gustatory cortex, including the anterior insula and frontal operculum, is responsible for taste perception. Tastestimuli are typically released when food is chewed, dissolved into saliva and predigested by oral enzymes, such as amylase, lipase, and proteases.

Ion channels mediate the recognition of salty and sour foods, most commonly by sodium ions from sodium chloride (Meddler and Kinnamon 2004). Acid protons give rise to sour taste generation. G-protein-coupled receptors (GPCRs) transmit sweet, bitter, and savory tastes to the brain (Lee and Owyang 2017, Roper 2007). Bitter compounds are recognized by type II GPCRs (T2Rs) (Chandrashekar et al. 2000). This type of receptor allows the recognition of unpleasant-tasting compounds, so it may be involved in the warning to avoid toxins (Peyrot et al. 2011).

The exact molecular mechanism of taste transduction differs for each taste, but they all cause transmitter release and increased firing of the afferent nerve.

\section{Salty taste}

$\mathrm{Na}^{+}$ions enter the cell receptors via amiloridesensitive Na-channels. This causes depolarization, and an influx of $\mathrm{Ca}^{2+}$ through voltage-sensitive $\mathrm{Ca}^{2+}$ channels, which leads to transmitter release (Roper et al. 2007).

\section{Sweet taste}

Binding to the receptor activates adenylyl cyclase, and cAMP (cyclic adenosin-monophosphate) elevation. This causes cAMP-dependent protein kinase (PKA)-mediated phosphorylation of $\mathrm{K}^{+}$channels. $\mathrm{Ca}^{2+}$ enters the cell through depolarization-activated $\mathrm{Ca}^{2+}$ channels and causes transmitter release (Zhang et al. 2010).

\section{Sour taste}

The concept of sour taste perception changed by discover of an acid-sensing channel - PKD2L1 (polycystin 2 like 1 channel), which is gated by $\mathrm{pH}$ $\left(\mathrm{H}^{+}\right.$ion concentration). This new evidence displaces the previous ones that $\mathrm{H}^{+}$ions block $\mathrm{K}^{+}$channels and cause a depolarization, or that $\mathrm{H}^{+}$ions enter the cell through $\mathrm{ENaC}$ (epithelial sodium channels). These mechanisms could exist but do not lead directly to sour perception (Huang et al. 2006).

\section{Bitter taste}

Binding to the $\mathrm{T} 2 \mathrm{R}$ receptors activates the G-protein. Diacylglycerols and $\mathrm{IP}_{3}$ (inositol triphosphate) as second messengers mediate release of $\mathrm{Ca}^{2+}$ from internal stores, which causes transmitter release and this increases the firing of the primary afferent nerve (Huang et al. 2006).

\section{Umami taste}

Binding to the receptor activates a G-protein and this may elevate intracellular $\mathrm{Ca}^{2+}$ (Kurihara and Kashiwayanagi 1998).

It is possible that specific receptors for the perception of fatty acids and calcium solutions exist. In rats, free fatty acids are deliberated by salivary lipase from triglycerides. Receptors for the free fatty acids are represented by type $\mathrm{CD} 36$ receptors, which were also identified in humans. Detection is probably mediated by G-protein coupled receptors (GPR40 and GPR120) and an influx of $\mathrm{Ca}^{2+}$ into the taste cells (Liu et al. 2016). Rats and chickens preferred the taste of calcium solution to water, when the calcium concentration in the solution was in the range of $0.04-0.5 \mathrm{mmol} / 1 \mathrm{CaCl}_{2}$. An opposite $\mathrm{U}$-shaped relation between calcium taste preference and calcium concentration also exists in humans (Tordoff 2001).

The threshold for the perception of each basic taste differs (Table 1). The principal determinants of taste thresholds are genetic, and taste thresholds do not vary considerably from day to day (Heath et al. 2006). Gustatory sensitivity declines with age. Adults tend to add more salt and spices to food than children. For example, the threshold for the sucrose (sweet perception) is $10 \mathrm{mmol} / \mathrm{l}$; in the case of $\mathrm{HCl}$ (hydrochloric acid), which represents bitter perception, is $0.9 \mathrm{mmol} / \mathrm{l}$. Saltiness perception can be represented by $\mathrm{NaCl}$ (natrium chloride $=$ salt), for this substance the threshold of perception is $10 \mathrm{mmol} / \mathrm{l}$, and this is equal to the sucrose 
threshold. Bitter taste can be noticed by a very low amount of quinine, exactly $0.008 \mathrm{mmol} / 1$ is enough for bitter perception, which is the lowest concentration from all the tastes. Umami is perceived by $0.7 \mathrm{mmol} / \mathrm{l}$ of glutamate (Purves et al. 2001).

It is important to point out that besides saccharides (mono-, di-, tri-, polysaccharides and sugar alcohols), many different chemical solutions can taste as sweet. Except the sulfonates, known as artificial sweeteners, such as cyclamate, acesulfam, stevia or saccharin, sweet taste can also be induced by some proteins (neotam, thaumatin, monellin), peptides (aspartame, alitam), aminoacides (leucine, asparagine, lysine), flavonoides (neohesperidine), terpenes, toxic organic (ethylenglycol) and anorganic (berylium chloride) compounds (Kurihara 1992).

Table 1. Summarization of the taste thresholds.

\begin{tabular}{lcc}
\hline Taste & Substance & Concentration \\
\hline Salty & $\mathrm{NaCl}$ & $0.01 \mathrm{M}$ \\
Sour & $\mathrm{HCl}$ & $0.0009 \mathrm{M}$ \\
Sweet & Sucrose & $0.01 \mathrm{M}$ \\
Bitter & Quinine & $0.000008 \mathrm{M}$ \\
Umami (savory) & ${\text { Glutamate } \mathrm{Na}^{+}}$ & $0.0007 \mathrm{M}$ \\
\hline
\end{tabular}

A recent study from 2017 offered very interesting results (Sollai et al. 2017). Authors tested sweet perception and preference by so-called PROP test, which is used in clinical studies for this purpose. PROP (6-n-propylthiouracil) is a prototypical bitter compound that can measure the direct human gustatory response by electrophysiological recording from the tongue. Subjects were classified for taster status (tasters versus non-tasters) and genotyped for the specific receptor gene (TAS2R38). Depolarization amplitude and rate were correlated with papilla density and perceived bitterness, and associated with taster status and TAS2R38. PROP test can also help predict the risk of dental caries in preschool and school children (Pidamale et al. 2012). In this study, children who were classified as non-tasters unable to perceive any taste, had increased dental caries compared to tasters, who had bitter perception. Another very interesting study described a positive relationship between non-taster status, sweetlikers, high caries index and low digit ratio 2D:4D, which was obtained by measuring the length ratio of the index finger to the ring finger (Lakshmi et al. 2016).
Besides the perceptive function, taste receptors can release several endocrine active substances, such as glucagon-like peptide, ghrelin, leptin, neuropeptide $Y$ and others, which are involved in the regulation of food intake (Calvo and Egan 2015). This release of endocrine active substances by taste receptors has an autocrine effect and other unknown functions. In the experimental model, leptin selectively suppresses and endocannabinoids selectively enhance sweet taste sensitivity via leptin receptor $(\mathrm{Ob}-\mathrm{Rb})$ and cannabinoid receptor type 1 (CB1) expressed in sweet taste sensitive cells at the peripheral gustatory organs (Yoshida et al. 2013).

The cephalic phase of insulin secretion is commonly ascribed to the complex signals from the visual, gustatory and olfactory system, together with anticipation based on previous experience. The cephalic phase of insulin secretion was studied on 15 healthy male volunteers by Dušková et al. (2013). The experiment consisted of mouth rinsing with either a sucrose or aspartate solution or pure water as a placebo. Authors described a short-term increase of insulin after rinsing with the glucose, but not after rinsing with the aspartate or placebo.

Taste serves for social communication in animals - for example in Drosophila it allows differentiation between male and female, mating status, and in vertebrates it can signalize dominancy. The question remains, whether ,gustatory“ evaluation plays a role in human interactions, such as kissing. However, it helps in social communication (for example social events, such as lunch/dinner) (Breslin 2013).

Apart from oral, there exists an extraoral taste perception. Taste sensors were identified in the lungs, gut, brain and reproductive system. The function of the extraoral taste perception is completely different from the oral:

- it can modulate the transport and resorption of glucose (sweet receptors in the gut)

- it can regulate the resorption of some substances of herbal origin (receptors for bitter in the gut)

- it is able to react on the potentially toxic compounds and microbes (receptors for bitter in the lungs) (Lipchock et al. 2011).

\section{Taste preference and its development}

The development of the olfactory (Chuah and Zheng 1987) and taste receptors begins at 7-8 weeks 
of gestation (Witt and Reutter 1997). The olfactory receptors are mature by the 24th week and the taste receptors around 17th week of gestation. Fetal swallowing begins around the 12th week of gestation and non-nutritive suckling at the 18th week. Near the end of gestation the fetus swallows a significant amount of amniotic fluid, and from the 24th week amniotic fluid is also inhaled. Between the 22nd and 25th weeks of gestation the taste signals are transmitted to the central nervous system. Fetus can react to the different tastes connected to mother's diet with changes of mimics and behavior. These changes can be detected by ultrasound. After birth, newborn babies start to react to different tastes in a few hours. For example, sweet taste causes positive reaction, such as rhythmic protrusion of the tongue or perking of lips (Ventura and Worobey 2013).

The study by Mennella and his co-workers (2001) deals with the impact of the pre- and perinatal exposition to some taste on the later food acceptance revers. In this study, pregnant women in the last trimester of the gravidity $(\mathrm{n}=46)$ were randomly divided into three groups. The first group received frozen organic carrot juice $(300 \mathrm{ml})$ during the pregnancy and water $(300 \mathrm{ml})$ during the lactation, the second did the opposite, and the third received water during both periods. They were instructed to drink at specific times of the day (10am-2pm), 4 times per week, for 3 consecutive weeks during the last trimester of the gravidity, and then during the first two months of lactation. At the age of $5.7 \pm 0.2$ months, meaning 4 weeks after, cereals were added. Before the introduction of carrot containing foods to the infants' diet, they were exposed to cereals to which water was added on testing day one, and carrot juice on testing day two. They were videotaped during the feeding. Infants who were exposed to the carrot flavor either prenatally or postnatally exhibited less negative facial responses while feeding the carrot-flavored cereals, whereas the control group exhibited the opposite tendency, although this was not significant. These results prove that initial experiences with tastes have an important impact on the later acceptance and enjoyment of food (Mennella et al. 2001).

Tube fed infants cannot experience the taste and smell of milk, because it bypasses the nasal and oral cavity. Additionally, these children miss the experience of sucking, swallowing, and chewing. When the same children start to be able to chew, they have problems accepting solid foods when introduced (Illingworth et al. 1964). In another study, infants were tube fed for at least
2 months (from birth). These children later refused any attempt at oral feeding (reacted by agitation, vomiting,...) and needed the longest time to transit to normal eating behavior (Senez et al. 1996).

Salty taste detection appears to develop later, perhaps between the 2 nd week and the 6th month of life (Beauchamp et al. 1986). Salt preference is influenced by prenatal experiences and is higher in infants whose mother experienced morning sickness during pregnancy (Crystal et al. 1998).

Children are most at risk for over-consuming sugar. Preference for sweet tastes is present early in life and is well conserved in primates (Steiner et al. 2001). Sweet preference remains present throughout childhood and starts declining to adult levels during mid-adolescence (Desor and Beauchamp 1987). Children of preschool age prefer higher concentrations of sucrose in water and lower concentrations of fat in pudding than their mothers. Preference of fat containing foods has a negative correlation to age (Mennella et al. 2012). Declination in sugar preference during adolescence could be associated with the cessation of growth (Coldwell et al. 2009). Hormonal changes during puberty could also play a role. Puberty is associated with changes in the secretion of insulin and leptin - both of which decrease sweet taste preference (Potau et al. 1997, Rodin et al. 1985). Cognitive factors may also play a part, because adults are more concerned about weight and health than children are. The knowledge of taste preference change during life is also used by tobacco companies for choosing the flavor of cigarettes, which is more preferable by adolescent (Hoffman et al. 2016).

Preference for sweet or salty tastes is generally reduced with advancing age until older adulthood (Liem and de Graaf 2004). Adults prefer more intense sweet, salty and sour tastes. This could be linked to the reduction of smell and taste sensitivity (Murphy and Withee 1986). Ovarian hormones also have influence on taste perception and preference. Good examples are pregnant and breastfeeding women who have decreased gustatory sensitivity. This could serve as a mechanism, which allows them to vary diet and to consume adequate electrolytes (Ochschenbein-Kolble et al. 2005). The sweet preference of pregnant women was significantly lower than that of nonpregnant women (Dippel and Elias 1980). Similar situations occur in postmenopausal women (Saluja et al. 2014).

Relatively little is known about developmental changes in sour, bitter and umami taste preference. Sour 
stimuli have no great nutritional value, with the exception of vitamin C. Evolutionary sour taste probably served to guide our ancestors to fruits, which are rich in vitamin $\mathrm{C}$.

The rejection of bitter taste is limited in newborns (birth-6 days), but is evident in older infants (14-180 days) (Kajiura et al. 1992). The aim of this refusal of bitter tastes probably serves as a protection mechanism against food, which could contain toxins (Glendinning 1994). However, bitter taste preference increases in early adolescence and aversion to this taste is attenuated with age (Forestell and Menella 2015).

Umami taste is not obvious in fresh meat. Hydrolyzed proteins have umami taste, so umami taste perhaps served as a marker of easily digested proteins in slightly aged or cooked meat (Milton 1999). An early sensitive period probably exists when flavor preference is established. Formulas containing protein hydrolysates are accepted by 4-month-old infants and younger without any problem (Mennella and Beauchamp 1996), whereas these hydrolysates are extremely unpalatable for adults and older children. Infants who consume a hydrolysate formula from early infancy readily continue to accept it after 5 months of age (Beauchamp et al. 1998). These observations suggest that there is a profound change at approximately 4 months of age in the infants' perception of these formulas and that early experience modifies later acceptance.

The importance of microbiome was understood recently. Microbiome is considered a true ecosystem, which includes $10^{14}$ microorganisms, with a wild spectrum of functions (digestion, maintenance of immune system, vitamins and enzymes production). The composition of microbiome is influenced by internal factors (as genotype, hormones, circadian rhythm) (Rácz et al. 2018) and external factors (as diet) (Kolátorová et al. 2018), but vice versa, it is possible that microbes of the gastrointestinal tract are able to "manipulate" the food intake of the host. There is a connection between cravings and composition of gut microbiota (for example, chocolate desiring individuals have different microbial metabolites in the urine than chocolate indifferent individuals) (Rezzi et al. 2007). Microbiota can affect mood and behavior too, which can be another way to influence food intake (Bercik et al. 2011). Both the fecal and oral microbiota are more similar among cohabiting family members compared to non-cohabiting individuals. Moreover, the microbial influence of food intake offers another somewhat surprising theory that food preference, which influences food consumption, could be contagious (Song et al. 2013), as well as obesity (Christakis and Fowler 2007, Dušátková et al. 2015, Hainer et al. 2015). Long-term preference of sweet food may affect oral microbiome and certainly creates the conditions for an increase of cariogenic streptococci. The clinical consequence of these changes in microbiome may be a higher incidence of dental caries.

Table 2. Etiology of taste disorder.

\begin{tabular}{|c|c|c|c|}
\hline Frequent & Less frequent & Unusual & Drugs \\
\hline $\begin{array}{c}\text { smoking } \\
\text { brain trauma } \\
\text { neurodegenerative diseases } \\
\text { age }\end{array}$ & $\begin{array}{c}\text { cocaine } \\
\text { nonpolar solvents } \\
\text { deficit of vitamin } \mathrm{A}, \mathrm{B} 6, \mathrm{~B} 12, \mathrm{Cu}, \mathrm{Zn} \\
\text { exposition to heavy metals } \\
\text { chronic liver failure } \\
\text { head irradiation }\end{array}$ & $\begin{array}{c}\text { brain tumor } \\
\text { psychiatric diseases } \\
\text { endocrine diseases } \\
\text { diabetes } \\
\text { epilepsy } \\
\text { cerebrovascular attacks } \\
\text { Sjögren syndrome } \\
\text { systemic lupus }\end{array}$ & $\begin{array}{c}\text { antibiotics } \\
\text { anticonvulsives } \\
\text { antidepressants } \\
\text { antihistamines } \\
\text { anti-inflammatory } \\
\text { drugs } \\
\text { chemotherapeutics } \\
\text { antiparkinsonics } \\
\text { antipsychotics } \\
\text { statins } \\
\text { myorelaxants }\end{array}$ \\
\hline
\end{tabular}

It is important to mention that other causes (as trusting in foods known from advertisements, not avoiding additives in food, etc.) play the role in the choosing of food for children. Unfavorable parental consumer attitudes are associated with a lower parental education level across Europe. Children of parents with unfavorable consumer attitudes eat more often sweet, fatty and processed foods and had a lower healthy diet 
adherence score. But parental consumer attitudes are not associated with children's fat, sweet and umami taste preferences (Jilani et al. 2018).

\section{Taste disorder}

Table 2 summarizes the possible factors which can lead to taste disorder (Bromley 2000). It is important to keep in mind that with the exception of some pathological conditions, such as neurodegenerative diseases or brain trauma, many frequently used drugs are responsible for changes of taste perception, which can have a negative impact on the quality of the individual's life.

\section{Conclusion}

The first few months of life are an essential part of the flavor learning process in humans. Taste is an important protective sense; it can help us avoid consuming foods which contain hazardous compounds (toxins, microbes...). In contrast to the fact that we are only able to differentiate 5 basic qualities of tastes (sweet, sour, salty, umami, bitter), we are able to recognize a wide spectrum of different flavors. Flavor is a result of a more complex sensation which requests, except taste perception, smell (by n.IX - olfactoric nerve) and perception of the food texture (by n.V - trigeminal nerve). Early experience with different tastes is very important for later acceptance of foods, especially the healthy ones. Although questions still remain about the exact development of taste preferences, by applying our current knowledge to infants, we can help to support the healthy development of children's taste preference and eating behavior. It means that parents play a crucial role in the development of taste preferences in their children, which has an impact on health and the health conditions connected to food intake (for example obesity, cardiovascular diseases...). The possibility to influence the incidence of some typical, food related illnesses in early childhood, or even before birth, offers us a very promising and interesting topic for further research.

\section{Conflict of Interest}

There is no conflict of interest.

\section{Acknowledgements}

The study was supported by grant: GACR 14-37368G (Grant Agency, Czech Republic), by project of the Ministry of Health of the Czech Republic - MH CZ DRO („Institute of Endocrinology - EÚ00023761“) and PROGRES Q 29/LF1 (Charles University, First Faculty of Medicine, Czech Republic).

\section{References}

BEAUCHAMP GK, MENNELLA JA: Sensitive periods in the development of human flavour perception and preference. Annales Nestlé 56: 19-31, 1998.

BEAUCHAMP GK, COWART BJ, MORAN M: Developmental changes in salt acceptability in human infants. Dev Psychobio 19: 17-25, 1986.

BERCIK P, DENOU E, COLLINS J, JACKSON W, LU J, JURY J, DENG Y, BLENNERHASSETTP, MACRI J, MCCOY KD, VERDU EF, COLLINS SM: The intestinal microbiota affect central levels of brain-derived neurotropic factor and behaviour in mice. Gastroenterology 141: 599-609, 2011.

BRESLIN PA: An evolutionary perspective on food and human taste. Curr Biol 23: 409-418, 2013.

BRESLIN PA, SPECTOR AC: Mammalian taste perception. Curr Biol 18: 148-155, 2008.

BROMLEY SM: Smell and taste disorders: a primary care approach. Am Fam Physician 61: 427-436, 438, 2000.

CALVO SS, EGAN JM: The endocrinology of taste receptors. Nat Rev Endocrinol 11: 213-227, 2015.

CHANDRASHEKAR J, MULLER KL, HOON MA, FENG L, GUO W, ZUKER CS, RYBA NJ: T2Rs function as bitter taste receptors. Cell 100: 703-711, 2000.

CHRISTAKIS NA, FOWLER JH: The spread of obesity in a large social network over 32 years. $N$ Engl J Med 357: 370-379, 2007.

CHUACH MI, ZHENG DR: Olfactory marker protein is present in olfactory receptor cells of human fetuses. Neuroscience 23: 363-370, 1987.

COLDWELL SE, OSWALD TK, REED DR: A marker of growth differs between adolescents with high vs. low sugar preference. Physiol Behav 96: 574-580, 2009. 
CRYSTAL SR, BERNSTEIN IL: Infant salt preference and mother's morning sickness. Apetite 30: 297-307, 1998.

DESOR JA, BEAUCHAMP GK: Longitudinal changes in sweet preference in humans. Physiol Behav 39: 639-641, 1987.

DIPPEL RL, ELIAS JW: Preferences for sweet in relationship to use of oral contraceptives and pregnancy. Horm Behav 14: 1-6, 1980.

DUŠKOVÁ M, MACOUREK M, ŠRÁMKOVÁ M, HILL M, STÁRKA L: The role of tastein cephalic phase of isilin secretion. Prague Med Rep 114: 222-230, 2013.

DUŠÁTKOVÁ L, ZAMRAZILOVÁ H, ALDHOON HAINEROVÁ I, ATKINSON RL, SEDLÁČKOVÁ B, LEE ZP, VČELÁK J, BENDLOVÁ B, KUNEŠOVÁ M, HAINER V: Association of adenovirus 36 infection with obesity-related gene variants in adolescents. Physiol Res 64 (Suppl 2): S197-S202, 2015.

FORESTELL CA, MENNELLLA J: The ontogeny of taste perception and preference throughout the childhood. In: Handbook of Olfaction and Gustation. DOTY RL (ed.), John Wiley \& Sons, Hoboken, New Jersey, 2015, pp 795-826.

GLENDINNING JI: Is the bitter rejection response always adaptive? Physiol Behav 56: 1217-1227, 1994.

HAINER V, ZAMRAZILOVÁ H, KUNEŠOVÁ M, BENDLOVÁ B, ALDHOON-HAINEROVÁ I: Obesity and infection: reciprocal causality. Physiol Res 64 (Suppl 2): S105-S119, 2015.

HEATH TP, MELICHAR JK, NUTT DJ, DONALDSON LF: Human taste thresholds are modulated by serotonin and noradrenaline. J Neurosci 26: 12664-12671, 2006.

HOFFMAN AC, SALGADO RV, DRESLER C, FALLER RW, BARTLETT C: Flavour preferences in youth versus adults: a review. Tob Control 25 (Suppl 2): ii32-ii39, 2016.

HUANG AL, CHEN X, HOON MA, CHANDRASHEKAR J, GUO W, TRANKER D, RYBA NJ, ZUKER CS: The cells and logic for mammalian sour taste detection. Nature 442: 934-938, 2006.

ILLINGWORTH RS, LISTER J: The critical or sensitive period, with special reference to certain feeding problems in infants and children. J Pediatr 65: 839-848, 1964.

JILANI HS, POHLABELN H, BUCHECKER K, GWOZDZ W, DE HENAUW S, EIBEN G, MOLNAR D, MORENO LA, PALA V, REISCH L, RUSSO P, VEIDEBAUM T, AHRENS W, HEBESTREIT A, IDEFICS CONSORTIUM: Association between parental consumer attitudes with their children's sensory taste preferences as well as their food choice. PLoS One 13: e0200413, 2018.

KAJIURA H, COWART BJ, BEAUCHAMP GK: Early developmental change in bitter taste responses in human infants. Dev Psychobiol 25: 375-386, 1992.

KOLÁTOROVÁ L, LAPČ́́K O, STÁRKA L: Phytoestrogens and the intestinal microbiome. Physiol Res 67 (Suppl 3): S401-S408, 2018.

KURIHARA Y: Characteristics of antisweet substances, sweet proteins, and sweetness-inducing proteins. Crit Rev Food Sci Nutr 32: 231-252, 1992.

KURIHARA K, KASHIWAYANAGI M: Introductory remarks on umami taste. Ann N Y Acad Sci 855: 393-397, 1998.

LAKSHMI CR, RADHIKA D, PRABHAT M, BHAVANA SM, SAI MADHAVI N: Association between genetic taste sensitivity, 2D:4D ratio, dental caries prevalence, and salivary flow rate in 6-14-year-old children: a crosssectional study. J Dent Res Dent Clin Dent Prospects 10: 142-147, 2016.

LAWLESS H, HEYMAN H: Sensory Evaluation of Food. Springer Science\& Business Media, New York, NY, 1999, pp 41-42.

LEE AA, OWYANG C: Sugars, sweet taste receptors, and brain responses. Nutrients 9: 653, 2017.

LI X, STASZEWSKI L, XU H, DURICK K, ZOLLER M, ADLER E: Human receptors for sweet and umami taste. Proc Natl Acad Sci U S A 99: 4692-4696, 2002.

LIEM DG, DE GRAAF C: Sweet and sour preferences in young children and adults: role of repeated exposure. Physiol Behav 83: 421-429, 2004.

LIPCHOCK SV, REED DR, MENNELLA JA: The gustatory and olfactory systems during infancy: implications for development of feeding behaviors in the high-risk neonate. Clin Perinatol 38: 627-641, 2011.

LIU D, ARCHER N, DUESING K, HANNAN G, KEAST R: Mechanism of fat taste perception: association with diet and obesity. Prog Lipid Res 63: 41-49, 2016.

LIU RH: Health-promoting components of fruits and vegetables in the diet. Adv Nutr 4: 384-392, 2013. 
MEDLER K, KINNAMON S: Transduction mechanisms in taste cells. In: Transduction Channels in Sensory Cells. FRINGS S, BRADLEY J (eds), Wiley-VCH, Weinheim, Germany, 2004, pp 153-174.

MENNELLA JA, BEAUCHAMP GK: Maternal diet alters the sensory qualities of human milk and the nursling's behavior. Pediatrics 88: 737-744, 1991.

MENNELLA JA, BEAUCHAMP GK: Developmental changes in the infants' acceptance of protein-hydrolysate formula and its relation to mothers' eating habits. J Dev Nebav Pediatr 17: 386-391, 1996.

MENNELLA JA, JOHNSON A, BEAUCHAMP GK: Garlic ingestion by pregnant women alters the odor of amniotic fluid. Chem Senses 20: 207-209, 1995.

MENNELLA JA, JAGNOW CJ, BEAUCHAMP GK: Pre- and postnatal flavor learning by human infants. Pediatrics 107: e88, 2001.

MENNELLA JA, FINKBEINER S, REED DR: The proof is in the pudding: children prefer lower fat but higher sugar than do mothers. Int J Obes 36: 1285-1291, 2012.

MILTON K: A hypothesis to explain the role of meat-eating in human evolution. Evol Anthropol 8: 11-21, 1999.

MURPHY C, WITHEE J: Age-related differences in the pleasantness of chemosensory stimuli. Psychol Aging 1: 312-318, 1986.

OCHSENBEIN-KOLBLE N, VON MERING R, ZIMMERMANN R, HUMMEL T: Changes in gustatory function during the course of pregnancy and postpartum. BJOG 112: 1636-1640, 2005.

PEYROT DG, BEAUCHAMP GK, STERN RM, KOCH KL, BRESLIN PA: Bitter taste induces nausea. Curr Biol 21: R247-R248, 2011.

PIDAMALE R, SOWMYA B, THOMAS A, JOSE T: Genetic sensitivity to bitter taste of 6-n Propylthiouracil: a useful diagnostic aid to detect early childhood caries in pre-school children. Indian J Hum Genet 18: 101-105, 2012.

POTAU N, IBANEZ L, RIQUE S, CARRASCOSA A: Pubertal changes in insulin secretion and peripheral insulin sensitivity. Horm Res 48: 219-226, 1997.

PURVES D, AUGUSTINE GJ, FITZPATRICK D, KATZ LC, LAMANTIA AS, MCNAMARA O, WILLIAMS SM (eds): Neuroscience. 2nd edition, Sinauer Associates, Sunderland, MA, 2001.

RÁCZ B, DUŠKOVÁ M, STÁRKA L, HAINER V, KUNEŠOVÁ M: Links between circadian rhytm, obesity and the microbiome. Physiol Res 67 (Suppl 3): S409-S420, 2018.

RAINE KD: Determinants of healthy eating in Canada: an overview and synthesis. Can J Public Health 96 (Suppl 3 ): S8-S14, 2005.

REZZI S, RAMADAN Z, MARTIN FP, FAY LB, VAN BLADEREN P, LINDO JC, NICHOLSON JK, KOCHBAR S: Human metabolic phenotypes link directly to specific dietary preferences in healthy individuals. J Proteome Res 6: 4469-4477, 2007.

RODIN J, WACK J, FERRANNINI E, DEFRONZO RA: Effect of insulin and glucose on feeding behavior. Metabolism 34: 826-831, 1985.

ROPER SD: Signal transduction and information processing in mammalian taste buds. Pflugers Arch 454: 759-776, 2007.

SALUJA P, SHETTY V, DAVE A, ARORA M, HANS V, MADAN A: Comparative evaluation of the effect of menstruation, pregnancy and menopause on salivary flow rate, $\mathrm{pH}$ and gustatory function. J Clin Diagn Res $\mathbf{8}$ : ZC81-ZC85, 2014.

SENEZ G, GUYS JM, MANCINI J, PAZPAREDES A, LENA G, CHOUX M: Weaning children from tube to oral feeding. Childs Nerv Syst 12: 590-594, 1996.

SOLLAI G, MELIS M, PANI D, COSSEDDU P, USAI L, CRNJAR R, BONFIGLIO A, TOMASSINI BARBAROSSA I: First objective evaluation of taste sensitivity to 6-n-propylthiouracil (PROP), a paradigm gustatory stimulus in humans. Sci Rep 7: 40353, 2017.

SONG SJ, LAUBER C, COSTELLO EK, LOZUPONE CA, HUMPHREY G, BERG-LYONS D, CAPORASO JG, KNIGHTS D, CLEMENTE JC, NAKIELNY S, GORDON JI, FIERER N, KNIGHT R: Cohabiting family members share microbiota with one another and with their dogs. eLife 2: e00458, 2013.

STEINER JE, GLASER D, HAWILO ME, BERRIDGE KC: Comparative expression of hedonic impact: affective reactions to taste by human infants and other primates. Neurosci Biobehav Rev 25: 53-74, 2001.

TORDOFF MG: Calcium: taste, intake, and appetite. Physiol Rev 81: 1567-1597, 2001. 
VENTURA AK, WOROBEY J: Early influences on the development of food preferences. Curr Biol 23: R401-R408, 2013.

WITT M, REUTTER K: Scanning electron microscopical studies of developing gustatory papillae in humans. Chem Senes 22: 601-612, 1997.

YOSHIDA R, NIKI M, JYOTAKI M, SANEMATSU K, SHIGEMURA N, NINOMIYA Y: Modulation of sweet responses of taste receptor cells. Semin Cell Dev Biol 24: 226-231, 2013.

ZHANG F, KLEBANSKY B, FINE RM, LIU H, XU H, SERVANT G, ZOLLER M, TECHJIAN C, LI X: Molecular mechanism of the sweet taste enhancers. Proc Natl Acad Sci U S A 107: 4752-4757, 2010. 